\title{
Potensi Cendawan Endofit Asal Jahe Merah (Zingiber officinale Roscoe) untuk Mengendalikan Cendawan Patogen Candida albicans In Vitro
}

\section{Potency of Endophytic Fungi Isolated From Zingiber officinale Roscoe to Control Pathogenic Fungus Candida albicans In Vitro}

\author{
MULYA SARI ${ }^{1}$, NAMPIAH SUKARNO ${ }^{*}$, IRMANIDA BATUBARA ${ }^{2,3}$, ROHANI CINTA BADIA BR \\ GINTING $^{4}$
}

\author{
'Departemen Biologi, Fakultas Matemetika dan Ilmu Pengetahuan Alam, IPB University, Bogor 16680, Indonesia \\ ${ }^{2}$ Departemen Kimia, Fakultas Matematika dan Ilmu Pengetahuan Alam, IPB University, Bogor 16680 \\ ${ }^{3}$ Pusat Studi Biofarmaka Tropika, IPB University, Bogor 16128, Indonesia \\ ${ }^{4}$ Balai Penelitian Tanah, Bogor 16114, Indonesia
}

Diterima 3 Juni 2020/Disetujui 6 September 2020

\begin{abstract}
Endophytic fungi isolated from red ginger (Zingiber officinale) can inhibit growth of Fusarium oxysporum, but the ability of the fungi to control Candida albicans as human pathogen has not been reported. The aims of this research were to study the mechanism of ten endophytic fungi isolates derived from red ginger to control $C$. albicans in vitro using dual culture methode and fungal extract, and to determine fungal bioactive chemical groups produced by the fungi. Three out of ten isolates tested, Talaromyces assiutensis JMa 7, T. assiutensis JMbt 3, and Curvularia affinis JMbt 9 inhibited growth of $C$. albicans with inhibition zones were $4.0 \mathrm{~mm}, 4.9 \mathrm{~mm}$, and $11.3 \mathrm{~mm}$, respectively. The cultures of the three potential endophytic fungi were extracted by maceration method using 3 solvents i.e ethyl acetate, $n$-hexane and ethanol. The three isolates were grown in PDB separately for 21 days incubation. At harvest, the culture filtrate was extracted by ethyl acetate and $n$-hexane, while fungal mycelia were extracted by all the three solvents. Ethyl acetate extracts obtained from culture filtrate of all the three fungal isolates consistently inhibited $C$. albicans with inhibition zones were $\mathbf{2 . 0 - 3 . 8} \mathbf{~ m m}$. For n-hexane extract, however, only Talaromyces assiutensis JMbt 3 that had positive effect with inhibition zone was $2.0 \mathrm{~mm}$. All extracts from mycelia did not have any effects on $C$. albicans. The ethyl acetate extract of $T$. assiutensis JMbt 3 was analysed to determine its chemical groups using visible color on thin layer chromatography (TLC). The results showed that the bioactive compounds was terpenoids, and antioxidant.
\end{abstract}

Key words: Endophytic fungi, Candida albicans, Culture filtrate, Solvents, Terpenoid

\section{PENDAHULUAN}

Cendawan endofit ialah cendawan yang hidup di dalam jaringan tumbuhan dan bersimbiosis secara mutualisme atau netral dengan inangnya. Cendawan endofit menghasilkan beragam senyawa metabolit sekunder diantaranya ialah senyawa alkaloid, peptida, steroid, terpenoid, fenol, kuinon, flavonoid, fenilpropanoid, senyawa alifatik, dan peptida (Yu et al. 2010; Mousa dan Raizada 2013). Senyawa metabolit sekunder cendawan endofit dapat dimanfaatkan untuk pengembangan bidang kesehatan yang diantaranya digunakan sebagai sumber antimikrob, antioksidan, antikanker dan antimalaria. Sebagai contoh ekstrak etil asetat filtrat cendawan endofit Penicillium sp. 1 yang diisolasi dari tanaman gandum (Triticum durum)

${ }^{*}$ Penulis korespondensi: +62-251-8622833

E-mail: ipi.sukarno@gmail.com sebagai pengendali C. albicans dan berpotensi sebagai antioksidan (Sadrati et al. 2013). Ekstrak klorofommetanol dari biomassa cendawan endofit Neurospora sp. asal tanaman Nothapodytes foetida dilaporkan menghasilkan camptothecin yaitu senyawa antikanker (Rehman et al. 2008). Ekstrak etil asetat media kultur cendawan endofit Fusarium sp. asal tanaman Mentha longifolia L. menghasilkan senyawa fusaripeptide A yaitu senyawa antimalaria (Ibrahim et al. 2017).

C. albicans ialah cendawan patogen oportunistik pada manusia yang menyebabkan penyakit kandidiasis. Cendawan tersebut menyerang respon imun (Dantas et al. 2016), dan epitelium vagina pada manusia (El-Din et al. 2012; Monroy-Pérez et al. 2016), sehingga memerlukan penanganan yang serius. Sampai saat ini obat yang digunakan untuk mengobati penyakit kandidiasis ialah senyawa dari golongan azole seperti ketokonazol (Siddik et al. 2016). Namun, penggunaan ketokonazol yang terusmenerus dapat menyebakan efek samping berupa 
kerusakan jaringan hati (liver injury) (Sparringa 2016). Selain itu, penggunaan ketokonazol dan golongan azole lainnya seperti flukonazol dapat menyebabkan $C$. albicans menjadi resisten terhadap senyawa-senyawa tersebut (Monroy-Pérez et al. 2016) karena dapat menyebabkan perubahan kromosom atau materi genetik. Oleh karena itu perlu mencari senyawa antimikrob lain, untuk pengobatan penyakit kandidiasis akibat infeksi C. albicans (Neu 1992).

Jahe merah merah ( $Z$. officinale) ialah tanaman yang digunakan sebagai herbal untuk flu, demam, antikanker, rematik, diabetes, komplikasi gastointestinal, mabuk perjalanan, antimikrob, dan antioksidan (Kundu et al. 2009; Noori et al. 2018). Senyawa bioaktif yang berasal dari tanaman jahe merah diduga berasal dari cendawan endofit yang berasosiasi dengan tanaman tersebut. Sebanyak sepuluh isolat cendawan endofit asal jahe telah berhasil diisolasi, diidentifikasi, dan dikoleksi di Bagian Mikologi IPB. Sebagian besar cendawan endofit tersebut dilaporkan dapat mengendalikan pertumbuhan patogen tanaman F. oxysporum (Ginting et al. 2013). Namun, potensi dari cendawan tersebut untuk mengendalikan cendawan patogen pada manusia seperti $C$. albicans belum diteiti.

Mekanisme cendawan endofit dalam mengendalikan cendawan patogen dilaporkan melalui 2 cara yaitu melalui mekanisme interaksi langsung dengan patogen dan melalui produksi senyawa bioaktif. Ekstraksi senyawa bioaktif yang dihasilkan oleh cendawan endofit memerlukan pelarut yang tepat. Oleh karena itu, penelitian ini bertujuan untuk mempelajari mekanisme pengendalian cendawan endofit asal jahe merah terhadap cendawan patogen C. albicans secara in vitro, memilih pelarut untuk ekstraksi senyawa bioaktif serta menentukan golongan senyawanya dan menentukan potensi ekstrak cendawan endofit sebagai antioksidan.

\section{BAHAN DAN METODE}

Bahan Penelitian. Bahan yang digunakan digunakan ialah Potato Dextrose Agar (PDA), Potato Dextrose Broth (PDB), cendawan endofit, cendawan patogen uji dan ketokonazol sebagai kontrol positif dalam pengujian. Cendawan endofit yang digunakan ialah 10 isolat cendawan endofit isolat koleksi laboratorium Bagian Mikologi IPB yang terdiri dari 6 spesies (Tabel 1) dan C. albicans (ATCC ${ }^{\circledR} 10231^{\mathrm{TM}^{*}}$ ) sebagai cendawan uji yang diperoleh dari Institut Pertanian Bogor Culture Collection (IPB CC).

Uji Antagonistik Cendawan Endofit terhadap C. albicans dengan Metode Kultur Ganda. Suspensi kultur C. albicans disiapkan dengan cara memasukkkan 1 jarum ose kultur berumur 24 jam dari media PDA ke dalam $20 \mathrm{ml}$ media PDB. Kultur pada media PDB diinkubasi pada suhu $37^{\circ} \mathrm{C}$ kemudian diukur nilai kerapatannya menggunakan spektrofotometer pada $\mathrm{OD}_{600}$ hingga nilai absorbansi
Tabel 1. Cendawan endofit asal jahe merah ( $Z$. officinale) (Ginting et al. 2013)

\begin{tabular}{lcc}
\hline Nama spesies & Kode isolat & Asal organ tanaman \\
\hline Fusarium solani & JMa 3 & Akar \\
Fusarium solani & JMa 5 & Akar \\
Talaromyces assiutensis & JMa 7 & Bkar \\
Talaromyces assiutensis & JMbt 3 & Batang \\
Curvularia affinis & JMbt 4 & Batang \\
Curvularia affinis & JMbt 9 & Batang \\
Glomerella cingulata & JMd 3 & Daun \\
Glomerella cingulata & JMd 5 & Daun \\
Beltraniella sp. & JMr 1 & Rimpang \\
$\begin{array}{l}\text { Colletotrichum } \\
\text { gleosporoides }\end{array}$ & JMr 2 & Rimpang \\
\hline
\end{tabular}

mencapai 0.8. Absorbansi dengan nilai 0.8 diperoleh pada inkubasi selama 16 jam. Selanjutnya dilakukan perhitungan jumlah koloni C. albicans menggunakan metode total plate count (TPC). Pengenceran yang dipilih ialah yang memiliki jumlah koloni 30-300. Dari hasil TPC diperoleh nilai kerapatan C. albicans ialah $10^{6} \mathrm{CFU} / \mathrm{ml}$.

Sebanyak $1 \mathrm{ml}$ kultur C. albicans dari media PDB yang telah diketahui kerapatannya diinokulasikan ke dalam $99 \mathrm{ml}$ media PDA bersuhu $35-40^{\circ} \mathrm{C}$. Kemudian media PDA yang berisi suspensi kultur dituang ke dalam cawan petri berdiameter $9 \mathrm{~cm}$ dan didiamkan hingga memadat. Media kultur segera digunakan untuk uji aktivitas anticendawan terhadap patogen $C$. albicans yang dilakukan dengan cara menempatkan kultur cendawan endofit berdiameter $6 \mathrm{~mm}$ di atas media PDA yang berisi suspensi $C$. albicans. Inkubasi dilakukan pada suhu $37^{\circ} \mathrm{C}$ selama 24 jam. Potensi cendawan endofit sebagai pengendali $C$. albicans diamati dengan terbentuknya zona hambat yaitu zona bening disekitar koloni cendawan endofit.

Ekstraksi dan Uji Aktivitas Ekstrak Cendawan Endofit terhadap Cendawan Patogen $C$. albicans. Tiga isolat yang mempunyai kemampuan menghambat C. albicans dari pengujian sifat antagonistik yaitu T. assiutensis JMa 7, T. assiutensis JMbt 3, dan $C$. affinis JMbt 9 digunakan untuk uji aktivitas ekstrak cendawan. Ekstraksi dilakukan terhadap filtrat kultur dan miselia tiga cendawan endofit tersebut. Setiap kultur cendawan endofit ditumbuhkan di dalam media PDB sebanyak 1.2 L secara terpisah selama 21 hari pada suhu $25^{\circ} \mathrm{C}$ menggunakan inkubator bergoyang dengan kecepatan $120 \mathrm{rpm}$. Filtrat kultur dan miselia cendawan endfit dipisahkan menggunakan penyaring vaccum. Filtrat kultur dimaserasi menggunakan dua pelarut secara terpisah yaitu etil asetat 1:1 $(\mathrm{v} / \mathrm{v})$, dan $n$-heksana 10:1 (v/v), sedangkan miselia cendawan dimaserasi dengan tiga pelarut yaitu etil asetat, $n$-heksana dan etanol secara terpisah dengan perbandingan 1:5 (b/v) antara miselia dengan pelarut. Maserasi dan ekstraksi diulang sebanyak 3 kali. Pelarut pada ekstrak diuapkan dengan rotary evaporator. Ekstrak yang diperoleh kemudian diencerkan menggunakan dimetil sulfoksida (DMSO) $10 \%$. Kontrol positif yang digunakan ialah senyawa ketokonazol dengan konsentrasi 1,000 ppm. Sebanyak 
$20 \mu 1$ ekstrak yang telah diencerkan selanjutnya diteteskan pada kertas cakram steril berdiameter $6 \mathrm{~mm}$ yang diletakkan tengah media pada cawan petri steril berukuran $9 \mathrm{~cm}$. Kertas cakram yang berisi ekstrak cendawan endofit diletakkan di atas media PDA yag berisi suspensi C. albicans. Inkubasi dilakukan pada suhu $37^{\circ} \mathrm{C}$ selama 24 jam. Aktivitas anticendawan dihitung berdasarkan diameter zona hambat yang terbentuk.

Penentuan Golongan Senyawa Kimia. Penentuan golongan senyawa kimia secara kualitatif dilakukan pada satu ekstrak isolat cendawan endofit terbaik yaitu ekstrak etil asetat dari filtrat kultur $T$. assiutensis JMbt 3 dengan menggunakan pereaksi yang merujuk pada metode Harborne (1996). Dugaan golongan senyawa aktif ditentukan menggunakan plat Kromatografi Lapis Tipis (KLT). Penotolan sampel menggunakan CAMAG Linomat 5 sebanyak $10 \mathrm{uL}$ dengan konsentrasi $10 \%$ pada pelat KLT. Elusi menggunakan pelarut pengembang yaitu etil asetat:etanol (9:1) di dalam bejana kromatogram sampai garis finish pada pelat KLT, kemudian pelat dikeringudarakan. Pelat hasil elusi dideteksi perubahan warna dan penentuan nilai Rfmenggunakan CAMAG Repsrostar 3 yang terintegrasi perangkat lunak WinCATS dengan lampu UV sinar tampak, 254 $\mathrm{nm}$ dan $366 \mathrm{~nm}$. Selanjutnya, sampel pada pelat KLT diberi pereaksi untuk mendeteksi golongan senyawa kimia yaitu golongan alkaloid, flavonoid, saponin, dan terpenoid secara kualitatif. Penentuan golongan senyawa alkaloid menggunakan pereaksi Dragendrof. Terbentuknya warna merah menunjukkan adanya senyawa golongan alkaloid. Senyawa flavonoid dideteksi dengan pereaksi $\mathrm{NH} 3$ yang akan membentuk warna kuning muda (Marliana et al. 2005). Senyawa saponin dideteksi dengan pereaksi vanilin-asam sulfat yang akan membentuk warna merah, kuning, biru tua, ungu, hijau, atau berupa kuning coklat jika reaksi positif (Wardhani dan Sulistyani 2012). Penentuan terpenoid dilakukan dengan pereaksi vanilin-asam sulfat pada suhu $100^{\circ} \mathrm{C}$ selama 10 menit. Perubahan warna menjadi ungu menunjukkan adanya terpenoid (Kusumaningtias et al. 2008). Pengamatan dilakukan dengan lampu uv sinar tampak.

Uji Bioautografi anti-C. albicans dengan Kromatografi Lapis Tipis (KLT). Ekstrak etil asetat filtrat kultur cendawan endofit $T$. assiutensis JMbt 3 dilarutkan dengan metanol hingga konsentrasi 5\%. Penotolan ekstrak pada pelat KLT menggunakan CAMAG Linomat 5. Elusi ekstrak pada pelat KLT di dalam bejana yang berisi pelarut pengembang etil asetat:etanol (9:1) sehingga diperoleh fraksifraksi ekstrak. Uji bioautografi dilakukan dengan menempatkan pelat KLT yang berisi fraksi-fraksi ekstrak tersebut di atas media yang berisi suspensi C. albicans. Inkubasi dilakukan pada suhu $37^{\circ} \mathrm{C}$ selama 18-24 jam. Pengamatan terhadap zona hambat yang terbentuk dengan menyemprotkan pewarna 2 , 3,5 triphenyl tetrazdium chloride (TTC) $(20 \mathrm{mg}$ dalam $10 \mathrm{ml}$ bufer fosffat $\mathrm{pH}$ 7) dan didiamkan 6-12 jam. Zona yang terbentuk pada bioautogram dibandingkan dengan nilai Rf yang telah dideteksi dengan lampu UV sinar tampak, $254 \mathrm{~nm}$ dan 366 $\mathrm{nm}$ untuk mengetahui $\mathrm{Rf}$ dari fraksi ekstrak yang memiliki aktivitas anticendawan.

Uji Antioksidan. Uji antioksidan dilakukan dengan menggunakan pelat KLT yang telah mengandung ekstrak etil asetat filtrat kultur cendawan endofit $T$. assiutensis JMbt 3 yang dielusi dengan pelarut pengembang etil asetat:etanol (9:1). Fraksifraksi ekstrak pada pelat KLT kemudian diberi pereaksi 1,1-difenil-2-pikrilhidrazil (DPPH) (10 mg dalam $10 \mathrm{ml}$ metanol). Pelat ekstrak diinkubasi pada suhu $37^{\circ} \mathrm{C}$ selama 15 menit. Pendeteksian aktivitas antioksidan menggunakan sinar uv dengan cara yang sama seperti penentuan golongan senyawa kimia dengan pelat KLT. Adanya aktivitas antioksidan ditunjukkan dengan bercak berwarna kuning dari fraksi ekstrak pada pelat KLT.

Analisis Data. Data hasil uji antagonistik dan esktrak cendawan endofit dianalisis menggunakan General Liner Model (GLM). Perbedaan nyata antar perlakuan dilanjutkan dengan uji Duncan Multiple Range Test (DMRT) pada taraf 5\% $(\mathrm{p}<0.05)$.

\section{HASIL}

Uji Antagonistik Cendawan Endofit terhadap C. albicans. Sebanyak sepuluh isolat cendawan endofit yang terdiri dari 6 spesies asal jahe merah (Z. officinale) diuji kemampuan antagonistiknya terhadap $C$. albicans. Hasil uji antagonistik menunjukkan bahwa tiga isolat dari 10 isolat yang diuji menghambat $C$. albicans. Tiga isolat tersebut ialah Talaromyces assiutensis JMa 7 menghasilkan nilai hambatan $4.0 \mathrm{~mm}, T$. assiutensis JMbt 3 menghasilkan nilai hambatan $4.9 \mathrm{~mm}$, dan Curvularia affinis JMbt 9 menghasilkan nilai hambatan 11.3 $\mathrm{mm}$ (Tabel 2, Gambar 1). Ketiga isolat cendawan endofit tersebut dipilih untuk pengujian lebih lanjut yaitu pengujian terhadap ekstrak kasarnya dalam menghambat pertumbuhan cendawan patogen $C$. albicans. Tujuh isolat cendawan endofit lainnya yaitu Fusarium solani JMa 3, Fusarium solani JMa 5, Culvularia affinis JMbt 4, Glomerella cingulata JMd 3, Glomerella cingulata JMd 5, Beltraniella sp. $\mathrm{JMr} 1$, dan Colletotrichum gleosporoides JMr 2 tidak menghambat $C$. albicans.

Aktivitas Ekstrak Cendawan Endofit terhadap C. albicans. Filtrat kultur cendawan endofit yang memiliki sifat antagonistik terhadap $C$. albicans yaitu T. assiutensis JMa 7, T. assiutensis JMbt 3, dan $C$. affinis JMbt 9, diekstraksi menggunakan dua pelarut yaitu etil asetat dan $n$-heksana. Seluruh esktrak etil asetat filtrat ketiga cendawan endofit tersebut menghambat cendawan patogen C. albicans dengan nilai diameter zona hambat yaitu $2.0-3.8 \mathrm{~mm}$. Hambatan tertinggi diperoleh dari ekstrak kasar 
etil asetat filtrat T. Assiutensis JMbt 3 dengan nilai diameter penghambatan sebesar $3.8 \mathrm{~mm}$ (Gambar 2). Kontrol negatif yaitu DMSO 10\% yang merupakan pelarut ekstrak cendawan endofit tidak berpengaruh

Tabel 2. Diameter zona hambat cendawan endofit asal jahe merah terhadap patogen Candida albicans

\begin{tabular}{|c|c|c|c|}
\hline Nama isolat & $\begin{array}{l}\text { Kode } \\
\text { isolat } h\end{array}$ & $\begin{array}{c}\text { Zona } \\
\text { hambat }(\mathrm{mm})\end{array}$ & $\begin{array}{l}\text { Ada/tidak hambatan } \\
\text { terhadap C. albicans }\end{array}$ \\
\hline Fusarium solani & JMa 3 & 0 & - \\
\hline Fusarium solani & JMa 5 & 0 & - \\
\hline Talaromyces & $\mathrm{JMa} 7$ & $4.0 \pm 0.9 \mathrm{c}$ & + \\
\hline assiutensis & & $4.9 \pm 1.0 \mathrm{~b}$ & + \\
\hline Talaromyces & JMbt 3 & 30 & - \\
\hline assiutensis & & $11.3 \pm 0.8 \mathrm{a}$ & + \\
\hline Culvularia affinis & JMbt 4 & 0 & - \\
\hline Culvularia affinis & JMbt 9 & 0 & - \\
\hline Glomerella cingulata & $a \mathrm{JMd} 3$ & 0 & - \\
\hline Glomerella cingulata & $a \mathrm{JMd} 5$ & 0 & - \\
\hline Beltraniella sp. & JMr 1 & & \\
\hline $\begin{array}{l}\text { Colletotrichum } \\
\text { gleosporoides }\end{array}$ & $\mathrm{JMr} 2$ & & \\
\hline
\end{tabular}

$(+)$ ada, (-) tidak ada hambatan

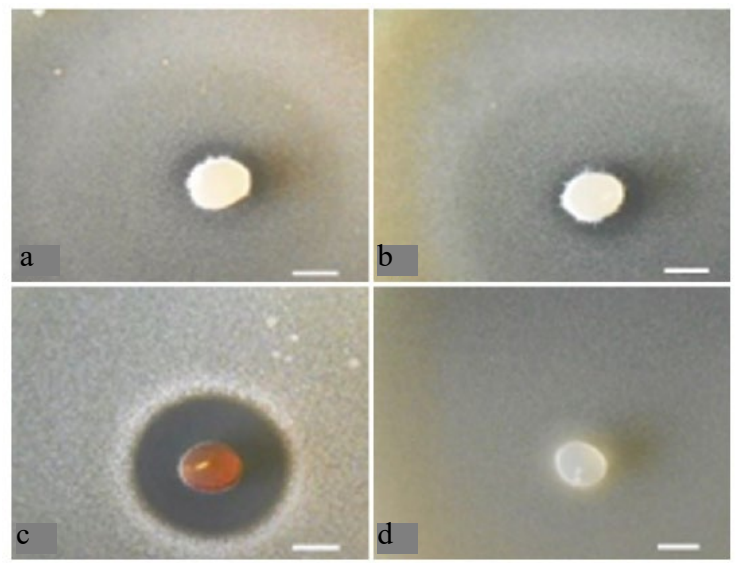

Gambar 1. Aktivitas penghambatan cendawan endofit asal Z. officinale terhadap Candida albicans. (a) $T$. assiutensis JMa 7, (b) T. assiutensis JMbt 3, (c) C. affinis JMbt 9, (d) kontrol. Skala batang di ujung kanan bawah $=5 \mathrm{~mm}$

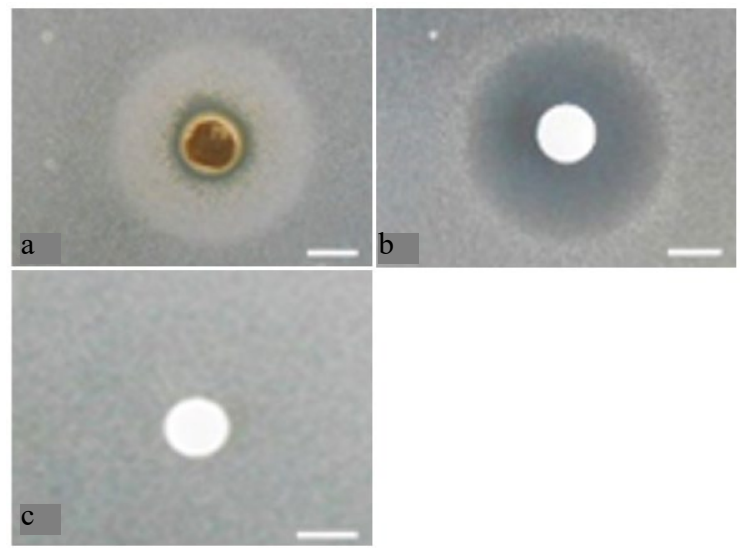

Gambar 2. Aktivitas penghambatan dari ekstrak kasar cendawan endofit terhadap patogen Candida albicans. (a) Ekstrak kasar etil asetat filtrat kultur T. assiutensis JMbt 3 terhadap C. albicans, (b) Ketokonazol 1,000 ppm $(\mathrm{K}+)$, (c) kontrol. Skala batang di ujung kanan bawah $=5 \mathrm{~mm}$ terhadap ketiga cendawan patogen $C$. albicans. Sedangkan pada pelarut $n$-heksana, hanya ekstrak $n$-heksana dari filtrat cendawan endofit $T$. assiutensis JMbt 3 yang menghasilkan penghambatan terhadap cendawan patogen $C$. albicans dengan nilai zona hambat $2 \mathrm{~mm}$ (Tabel 3). Ekstrak miselia 3 cendawan endofit yang diekstraksi dengan 3 pelarut yaitu etil asetat, $n$-heksana dan etanol yang diujikan tidak menghambat cendawan patogen $C$. albicans (data tidak ditampilkan).

Penentuan Golongan Senyawa Kimia. Penentuan golongan senyawa kimia dari ekstrak yang paling berpotensi yaitu ekstrak etil asetat dari filtrat kultur T. assiutensis JMbt 3 ditentukan secara kualitatif dengan 2 metode yaitu menggunakan pereaksi secara langsung dan berdasarkan penampakan pada kromatografi lapis tipis. Pada uji tersebut senyawa alkaloid tidak membentuk endapan jingga, putih dan coklat; senyawa flavonoid tidak menghasilkan warna jingga; senyawa saponin tidak menghasilkan buih, dan senyawa terpenoid tidak membentuk warna ungu tetapi terbentuk warna kuning. Hasil ini menunjukkkan bahwa tidak terdeteksi golongan senyawa dari ekstrak etil asetat filtrat kultur T. assiutensis JMbt 3. Konfirmasi uji kualitatif dilakukan dengan menggunakan pelat kromatografi lapis tipis (KLT). Hasil konfirmasi menggunakan pelat kromatografi lapis tipis (KLT) diperoleh sepuluh bercak yang terdiri dari satu bercak dideteksi sebagai golongan terpenoid dengan terbentuknya warna ungu pada pereaksi vanilin-asam sulfat yaitu pada Rf 0.94 (Tabel 4).

Uji Bioautografi anti-C. albicans. Bioautogram senyawa pengendali ekstrak etil asetat filtrat kultur $T$. assiutensis JMbt 3 dalam menghambat pertumbuhan $C$. albicans disajikan pada Gambar 3. Pada bioautogram, senyawa pengendali $C$. albicans tidak membentuk zona hambat yang spesifik pada 10 bercak ekstrak etil asetat filtrat kultur T. assiutensis JMbt 3. Sedangkan kontrol positif ketokonazol terbentuk zona yang menunjukkan adanya hambatan pertumbuhan C. albicans.

Aktivitas Antioksidan. Uji aktivitas antioksidan dilakukan untuk mengetahui kemampuan ekstrak etil asetat filtrat kultur T. assiutensis JMbt 3 dalam menghasilkan senyawa yang berfungsi sebagai antioksidan. Sepuluh bercak ekstrak etil asetat filtrat $T$. assiutensis $\mathrm{JMbt} 3$ pada pelat kromatografi lapis tipis, diperoleh empat bercak positif sebagai antioksidan

Tabel 3. Diameter zona hambat ekstrak kasar filtrat kultur cendawan endofit asal Z. officinale Rosc. $(336,000$ $\mu \mathrm{g} / \mathrm{ml}$ ) terhadap patogen Candida albicans

\begin{tabular}{llc}
\hline \multirow{2}{*}{ Ekstrak kasar } & \multicolumn{2}{c}{ Zona hambat (mm) } \\
\cline { 2 - 3 } & etil asetat & $n$-heksana \\
\hline T. assiutensis JMa 7 & $2.0 \pm 0.0 \mathrm{c}$ & $0.0 \pm 0.0 \mathrm{~d}$ \\
T. assiutensis JMbt 3 & $3.8 \pm 0.6 \mathrm{~b}$ & $2.0 \pm 0.0 \mathrm{c}$ \\
C. affinis JMbt 9 & $2.0 \pm 0.0 \mathrm{c}$ & $0.0 \pm 0.0 \mathrm{~d}$ \\
\hline K
\end{tabular}

Ketokonazol 1000 ppm (K+) $17.3 \pm 0.3 \mathrm{a}$

$\operatorname{DMSO}(\mathrm{K}-) \quad 0.0 \pm 0.0 \mathrm{~d}$

angka-angka pada baris yang sama diikuti dengan huruf yang sama tidak berbeda nyata pada taraf 5\% (uji nilai berganda Duncan) 
Tabel 4. Nilai Rf dan penampakan bercak pada kromatografi lapis tipis (KLT) ekstrak kasar etil asetat filtrat kultur Talaromyces assiutensis JMbt 3

\begin{tabular}{|c|c|c|c|c|c|c|c|c|c|}
\hline \multirow{2}{*}{$\mathrm{Rf}$} & \multicolumn{3}{|c|}{ Sebelum diberi pereaksi } & \multicolumn{5}{|c|}{ Setelah diberi pereaksi } & \multirow{2}{*}{$\begin{array}{l}\text { Ket. golongan senyawa, } \\
\text { bersifat antioksidan }\end{array}$} \\
\hline & Visual & $254 \mathrm{~nm}$ & $366 \mathrm{~nm}$ & $\begin{array}{l}\text { Alkaloid } \\
\text { (pereaksi } \\
\text { dragendrof) }\end{array}$ & $\begin{array}{c}\text { Flavonoid } \\
\left({\left.\text { pereaksi } \mathrm{NH}_{3}\right)}\right)\end{array}$ & $\begin{array}{l}\text { Saponin } \\
\text { (pereaksi } \\
\text { Van- } \mathrm{H}_{2} \mathrm{SO}_{4} \text { ) }\end{array}$ & $\begin{array}{l}\text { Terpenoid } \\
\text { (pereaksi } \\
\text { Vanilin- } \mathrm{H}_{2} \mathrm{SO}_{4} \\
\text { oven } 100^{\circ} \mathrm{C} \text { ) }\end{array}$ & $\begin{array}{c}\text { Antioksidan } \\
\text { (pereaksi DPPH) }\end{array}$ & \\
\hline 0.71 & - & hitam & biru & - & abu-abu & - & hitam & kuning & antioksidan \\
\hline 0.73 & - & abu-abu & biru & - & - & - & abu-abu & - & - \\
\hline 0.75 & - & abu-abu & biru & - & - & - & - & - & - \\
\hline 0.80 & - & abu-abu & biru & - & - & - & - & - & - \\
\hline 0.83 & - & hitam & biru & hitam & - & - & abu-abu & kuning & antioksidan \\
\hline 0.88 & - & - & biru & - & - & - & - & - & - \\
\hline 0.90 & - & abu-abu & merah & - & - & - & - & - & - \\
\hline 0.92 & - & abu-abu & - & - & - & - & - & kuning & antioksidan \\
\hline 0.94 & - & abu-abu & biru & - & - & - & ungu & kuning & terpenoid, antioksidan \\
\hline$\underline{0.98}$ & - & abu-abu & biru & - & - & - & - & - & - \\
\hline
\end{tabular}

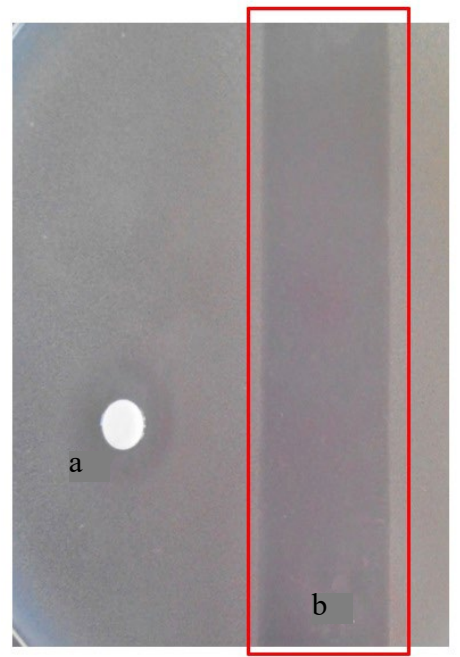

Gambar 3. Bioautogram anti-Candida albicans pada (a) kontrol positif ketokonazol $500 \mathrm{ppm}(\mathrm{K}+)$ dan (b) ekstrak etil asetat filtrat kultur Talaromyces assiutensis JMbt 3

dengan ditandai terbentuknya warna kuning setelah diberi pereaksi DPPH pada Rf 0.71, Rf 0.83, Rf 0.92, dan Rf 0.94 (Tabel 4).

\section{PEMBAHASAN}

Tiga dari sepuluh isolat cendawan endofit yaitu Talaromyces assiutensis JMa 7, T. assiutensis JMbt 3 dan Curvularia affinis JMbt 9 menghambat cendawan patogen $C$. albicans ditandai dengan terbentuknya zona hambat pada uji antagonistik. Menurut Yadav et al. (2014) zona hambat yang mempunyai aktivitas terbaik ialah berdiameter $8-13 \mathrm{~mm}$. Oleh karena itu cendawan endofit $C$. affinis JMbt 9 merupakan isolat potensial untuk menghambat $C$. albicans karena memiliki nilai hambatan sebesar $11.3 \mathrm{~mm}$. Tujuh isolat cendawan endofit yang terdiri dari 5 spesies yaitu Fusarium solani JMa 3, Fusarium solani JMa 5, Culvularia affinis JMbt 4, Glomerella cingulata JMd 3, Glomerella cingulata JMd 5, Beltraniella sp. JMr 1, dan Colletotrichum gleosporoides JMr 2 tidak menghambat $C$. albicans. Penelitian lain melaporkan bahwa $F$. solani yang diisolasi dari tanaman Taxus baccata menghasilkan metabolit yang diekstrak dengan etil asetat dari filtrat kultur yang dapat menghambat $C$. albicans (Tayung et al. 2011). Cendawan endofit C. gleosporoides yang diisolasi dari tanaman Rauwolfia serpentina menghasilkan ekstrak etanol dari filtrat kultur yang dapat menghambat C. albicans (Nath et al. 2015). Sedangkan untuk cendawan endofit dengan spesies yang sama Culvularia affinis, Glomerella cingulata dan Beltraniella sp. belum ditemukan laporan lainnya apakah dapat menghambat pertumbuhan C. albicans. Dari hasil ini diketahui bahwa spesies yang sama memiliki potensi yang berbeda dalam menghambat cendawan patogen yang sama, perbedaan ini terjadi pada tingkatan strain.

Seluruh ekstrak filtrat cendawan endofit $T$. assiutensis $\mathrm{JMa} 7, T$. assiutensis $\mathrm{JMbt} 3$, dan $C$. affinis JMbt 9 dengan pelarut etil asetat menghambat cendawan patogen $C$. albicans. Namun, pada pelarut $n$-heksana, hanya T. assiutensis JMbt 3 yang menghambat patogen uji. Hal ini menunjukkan senyawa aktif pada cendawan ialah golongan senyawa semipolar, sedangkan senyawa polar pada ekstrak $n$-heksana kurang aktif. Nilai penghambatan masingmasing cendawan patogen lebih rendah dari kontrol positif yaitu ketokonazol. Hal ini menunjukkan bahwa ekstrak etil asetat dan $n$-heksana filtrat $T$. assiutensis JMbt 3 mempunyai potensi menghambat cendawan patogen $C$. albicans walaupun masih di bawah kemampuan obat komersil. Dengan kata lain, cendawan endofit yang diuji mempunyai potensi untuk ditingkatkan kemampuan ekstraknya jika dilakukan optimasi pertumbuhannya dengan cara mengubah kondisi lingkungan seperti suhu, media, $\mathrm{pH}$ dan lainnya atau dapat juga melalui rekayasa genetika.

Ekstrak etil asetat dan $n$-heksana dari filtrat kultur cendawan endofit dengan spesies yang sama yaitu $T$. assiutensis dari isolat yang berbeda yaitu $T$. assiutensis JMa 7 dan T. assiutensis JMbt 3 memiliki kemampuan yang berbeda dalam menghambat patogen C. albicans. Ekstrak etil asetat filtrat kultur dari kedua isolat dapat menghambat $C$. albicans. 
Sedangan, hanya ekstrak $n$-heksana dari filtrat kultur T. assiutensis JMbt 3 yang dapat menghambat $C$. albicans. Hal ini menujukkan bahwa kedua isolat tresebut ada perbedaan ditingkat strain. Dari hasil uji golongan senyawa ekstrak etil asetat dari filtrat kultur T. assiutensis JMbt 3 terdeteksi mengandung senyawa terpenoid. Menurut Liu et al. 2007 bahwa ekstrak dari cendawan endofit Xylaria sp. asal tanaman Ginkgo biloba yang diekstraksi dengan berbagai pelarut seperti heksana, kloroform, etil asetat, aseton, dan metanol menghasilkan golongan senyawa yang sama meskipun dengan total kandungan senyawa yang beragam. Hal ini menunjukkan bahwa ekstrak etil asetat dari filtrat kultur T. assiutensis JMa 7 mungkin memiliki golongan senyawa yang sama dengan $T$. assiutensis JMbt 3 yaitu terpenoid.

Penghambatan yang efektif terhadap patogen C. albicans adalah ekstrak yang berasal dari filtrat kultur cendawan endofit. Hal ini menunjukkan bahwa senyawa bioaktif yang potensial ialah bersifat ekstraselular yaitu metabolit sekunder cendawan endofit yang dikeluarkan dari sel ke medium pertumbuhan cendawan endofit (filtrat). Hal ini sejalan dengan penelitian Macías-Rubalcava et al. (2010) bahwa penghambatan ekstrak filtrat cendawan endofit Muscodor yucatanensis asal tanaman Bursera simaruba yang diekstraksi dengan pelarut kombinasi dari diklorometan dan etil setat berpotensi sebagai anticendawan dibandingkan ekstrak dari miselia. Akan tetapi, tidak semua ekstrak cendawan endofit berasal dari miselia tidak dapat menghambat $C$. albicans. Malhadas et al. (2017) melaporkan bahwa selain esktrak etil asetat yang berasal dari filtrat kultur, ekstrak etil asetat dari miselia cendawan endofit Alternaria alternata yang berasal dari tanaman Olea europaea L. menghambat pertumbuhan cendawan patogen $C$. albicans. Selain itu ekstrak dari filtrat kultur dan miselia dengan pelarut etil asetat dapat menghambat cendawan patogen lainnya seperti Bacillus subtilis, Bacillus cereus, Staphyloccocus aureus, Escherichia coli, Candida glabrata, dan Candida parapsilosis. Namun dalam penelitian ini hanya ekstrak filtrat yang mempunyai aktivitas mengendalikan C. albicans.

Pelarut yang dapat mengekstraksi senyawa metabolit teraktif dari filtrat ketiga cendawan endofit terbaik ialah etil asetat. Etil asetat merupakan pelarut yang paling banyak digunakan dalam mengekstraksi metabolit sekunder karena sifatnya yang semipolar sehingga dapat mengikat senyawa kimia lebih beragam. Etil asetat merupakan pelarut yang paling efisien dalam memperoleh metabolit sekunder (Yadav et al. 2014), dibandingkan pelarut heksana, metanol dan butanol serta menghasilkan jumlah ekstrak yang lebih tinggi (Kumar dan Kaushik 2013).

Berdasarkan kromatogram bercak pada Rf 0.94 pada ekstrak etil asetat filtrat $T$. assiutensis JMbt 3 merupakan golongan senyawa terpenoid dan juga bersifat antioksidan. Tiga bercak pada Rf 0.71 , Rf
0.83, dan Rf 0.92 yang aktif sebagai antioksidan tidak diketahui golongannya, karena tidak membentuk warna spesifik. Terpenoid ialah golongan senyawa yang umum dihasilkan oleh cendawan endofit. Ekstrak metanol dari seluruh bagian kultur cendawan endofit Talaromyces flavus (miselia dan filtrat kultur) asal mangrove Sonneratia apetala dilaporkan menghasilkan terpenoid talaperoxides A-D dari kelompok norsesquiterpene ( $\mathrm{Li}$ et al. 2011). Ekstrak etanol dari filtrat kultur cendawan endofit Aspergillus awamori dari tanaman Rauwolfia serpentina mengandung golongan senyawa terpenoid yang menghambat $C$. albicans (Nath et al. 2015). Ektrak etil asetat dari seluruh kultur cendawan endofit Talaromyces islandicus EN-501 asal alga merah Laurencia okamurai menghasilkan metabolit hydroanthraquinones berpotensi sebagai anticendawan dan antioksidan ( $\mathrm{Li}$ et al. 2017). Sedangkan, pada penentuan golongan senyawa menggunakan pereaksi langsung di dalam ekstrak kasar cendawan endofit $T$. assiutensis JMbt 3, tidak menunjukkan warna spesifik. Diduga terdapat banyaknya senyawa yang terkandung di dalam ekstrak sehingga pereaksi tidak bereaksi efektif dengan senyawa target pada ekstrak cendawan endofit.

Senyawa golongan terpenoid memiliki kemampuan menghambat pertumbuhan C. albicans. Ekstrak etil asetat filtrat kultur dan miselia dari cendawan endofit Alternaria alternata yang berasal dari tanaman Olea europaea L. berpotensi sebagai anticendawan $C$. albicans dengan dihasilkannya senyawa 3-methyl1-butanol, 3-methyl-1-butanol acetate, phenylethyl alcohol, $\beta$-cedrene, thujopsene (Malhadas et al. 2017). Diantara senyawa-senyawa tersebut, senyawa $\beta$-cedrene dan thujopsene merupakan senyawa dari golongan terpenoid.

Senyawa antimikrob menghambat patogen melalui berbagai mekanisme. Agen antimikrob menyebabkan kerusakan pada komponen penyusun dinding sel, ganguan membran sitoplasma, terhambatanya proses sintesis protein dan ganguan terhadap senyawa metabolik (Neu 1992; Kohanski et al. 2010). Pada penelitian ini diduga senyawa yang berasal dari filtrat kultur cendawan endofit asal jahe merah menyebabkan ganguan terhadap komponen penyusun dinding sel sehingga pertumbuhan $C$. albicans terhambat yang ditunjukkan dengan terbentuknya zona hambat.

Fraksi-fraksi senyawa pada pelat KLT pada uji bioautografi anticendawan tidak menunjukkan adanya zona hambat. Sedangkan, hasil pengujian ekstrak yang mengandung kelompok senyawa menghasilkan penghambatan terhadap C. albicans. Diduga karena konsentrasi senyawa target menjadi rendah setelah dipisahkan pada kromatografi.

Berdasarkan hasil penelitian disimpulkan bahwa dari sepuluh spesies cendawan endofit diuji sifat antagonistiknya terhadap patogen $C$. albicans diperoleh 3 cendawan endofit yaitu Talaromyces assiutensis JMa 7, T. assiutensis JMbt 3 dan Curvularia 
affinisutensis JMbt 9 sedangkan 7 isolat cendawan endofit lainnya tidak berpotensi menghambat $C$. albicans. Hasil uji ekstrak metabolit dari filtrat ketiga cendawan endofit tersebut, hanya satu isolat Talaromyces assiutensis JMbt 3 yang memiliki potensi pengendalian terhadap C. albicans. Produksi senyawa bioaktif teraktif menggunakan filtrat kultur dengan pelarut etil asetat. Golongan senyawa kimia yang terdeteksi di dalam ekstrak etil asetat dari filtrat kultur T. assiutensis JMbt 3 ialah dari golongan terpenoid yang berfungsi sebagai anticendawan dan antioksidan.

\section{DAFTAR PUSTAKA}

Dantas ADS, Lee KK, Raziunaite I, Schaefer K, Wagener J, Yadav B, Gow NAR. 2016. Cell biology of Candida albicans-host interactions. Current Opinion in Microbiol 34:111-118.

El-Din AAK, Al-Basri HM, El-Naggar NY. 2012. Critical factors affecting the adherence of Candida albicans to the vaginal epithelium. J Taibah University for Sci 6:10-18.

Ginting RCB, Sukarno N, Widyastuti U, Darusman LK, Kanaya S. 2013. Diversity of endophitic fungi from red ginger (Zingiber officinale Rosc.) plant and their inhibitory effect to Fusarium oxysporum plant pathogenic fungi. HAYATI $J$ of Biosci 20:127-137.

Harborne JB. 1996. Metode Fitokimia: Penuntun Cara Modern Menganalisis Tumbuhan. ITB. Bandung.

Ibrahim SR, Abdallah HM, Elkhayat ES, Al Musayeib NM, Asfour HZ, Zayed MF, Mohamed GA. 2017. Fusaripeptide a:new antifungal and anti-malarial cyclodepsipeptide from the endophytic fungus Fusarium sp. $J$ of Asian natural products research 20:75-85.

Kohanski MA, Dwyer DJ, Collins JJ. 2010. How antibiotics kill bacteria: from targets to etworks. Nat rev Microbiol 8:423-435.

Kundu JK, Na HK, Surh YJ. 2009. Ginger-derived phenolic substances with cancer preventive and therapeutic potential. Food Factors for Health Promotion 61:182-192.

Kumar S, Kaushik N. 2013. Endophytic fungi isolated from oilseed crop Jatropha curcas produces oil and exhibit antifungal activity. PLoS ONE 8:1-8.

Kusumaningtiyas E, Sukmawati L, Astuti E. 2008. Penentuan golongan bercak senyawa aktif ekstrak $n$-heksan Alpinia galanga terhadap Candida albicans dengan Bioautografi dan kromatografi lapis tipis. JITV 13:323-328.

Li H, Huang H, Shao C, Huang H, Jiang J, Zhu X, Liu Y, Liu $\mathrm{L}, \mathrm{Lu} \mathrm{Y}, \mathrm{Li} \mathrm{M}$ et al. 2011. Cytotoxic norsesquiterpene peroxides from the endophytic fungi Talaromyces flavus isolated from the mangrove plant sonneratia apetala. $J$ Nat Prod 74:1230-1235.

Li HL, Li XM, Li X, Wang CY, Liu H, Kassack MU, Meng LH, Wang BG. 2017. Antioxidant hydroanthraquinones from the marine algal-derived endophytic fungi Talaromyces islandicus EN-501. J Nat Prod 80:162-168.

Liu X, Dong M, Chen X, Jiang M, Lv X, Yan G. 2007. Antioxidant activity and phenolics of an endophytic Xylaria sp. from Ginkgo biloba. Food chemistry 105:548-554

Macías-Rubalcava ML, Ernández-Bautista BE, Oropeza F, Duarte G, González MC, Glenn AE, Hanlin RT, Anaya AL. 2010. Allelochemical effects of volatile compounds and organic extracts from Muscodor yucatanensis, a tropical endophytic fungi from Bursera simaruba. J Chem Ecol 36:1122-1131.
Malhadas C, Malheiro R, Pereira JA, de Pinho PG, Baptista P. 2017. Antimicrobial activity of endophytic fungi from olive tree leaves. World J Microbiol Biotechnol 33:46.

Marliana SD, Suryanti V, Suyono. 2005. Skrining fitokimia dan analisis kromatografi lapis tipis komponen kimia buah labu siam (Sechium edule Jacq. Swartz.) dalam ekstrak etanol. Biofarmasi 3:26-31.

Monroy-Pérez E, Gloria Luz Paniagua-Contreras, Pamela Rodríguez-Purata, Felipe Vaca-Paniagua, Marco VázquezVillaseñor, Clara Díaz-Velásquez, Alina Uribe-García, Sergio Vaca. 2016. High virulence and antifungal resistance in clinical strains of Candida albicans. Canadian J of Infectious Diseases and Medical Microbiology 2016:1-7.

Mousa WK, Raizada MN. 2013. The diversity of anti-microbial secondary metabolites produced by fungal endophytes:an interdisciplinary perspective. Frontiers in microbiology $4: 1-18$.

Nath A, Chattopadhyay A, Joshi SR. 2015. Biological activity of endophytic fungi of Rauwolfia serpentina Benth:an ethnomedicinal plant used in folk medicines in Northeast India. In: Proceedings of the National Academy of Sciences India Section B: Biological Sciences. Allahabad:Springer. p. 233-240.

Neu HC. 1992. The crisis in antibiotic resistance. Science 257:1064-1073.

Noori S, Zeynali F, Almasi H. 2018. Antimicrobial and antioxidant efficiency of nanoemulsion-based edible coating containing ginger (Zingiber officinale) essential oil and its effect on safety and quality attributes of chicken breast fillets. Food Control 84:312-320.

Rehman S, Shawl AS, Kour A, Andrabi R, Sudan P, Sultan P, Verma V, Qazi GN. 2008. An endophytic Neurospora sp. from Nothapodytes foetida producing camptothecin. Appl Biochem and Microbiol 44:203-209.

Sadrati N, Daoud H, Zerroug A, Dahamna S, Bouharati S. 2013. Screening of antimicrobial and antioxidant secondary metabolites from endophtic fungi isolated from wheat (Triticum durum). J of Plant Protection Research 53:128136.

Sparringa RA. 2016. Laporan Tahunan BPOM 2015. Tersedia pada: https://www.pom.go.id/ppid/2016/kelengkapan/ laptah2015.pdf [tanggal diakses: 23 Februari 2018]

Siddik MB, Yulia L, Edyson. 2016. Perbandingan efektivitas anticendawan antara ekstrak metanol kulit batang kasturi dengan ketokonazol 2\% terhadap Candida albicans in vitro. Berkala Kedokteran 12:271-278.

Tayung K, Barik BP, Jha DK, Deka DC. 2011. Identification and characterization of antimicrobial metabolite from an endophytic fungus, Fusarium solani isolated from bark of Himalayan yew. Mycosphere 2:203-213.

Wardhani LK, Sulistyani N. 2012. Uji aktivitas antibakteri ekstrak etil asetat daun binahong (Anredera scandens (L.) Moq.) terhadap Shigella flexneri beserta profil kromatografi lapis tipis. J Ilmiah Kefarmasian 2:1-16.

Yadav M, Yadav A, Kumar S, Sharma D, Yadav J P. 2014. Evaluation of In vitro antimicrobial potential of endophytic fungi isolated from eugenia jambolana lam. Inter $J$ of Pharmacy and Pharmaceutical Sciences 6:208-211.

Yu H, Zhang L, Li L, Zheng C, Guo L, Li W, Sun P, Qin L. 2010. Recent developments and future prospects of antimicrobial metabolites produced by endophytes. Microbiological Research 165:437-449. 